\title{
Prevalence of Asymptomatic Bacteriuria in Pregnancy and Urinary Tract Infection in Non-pregnant Symptomatic Womem
}

\author{
Smart Enoch Amala ${ }^{1 *}$, Rita Karibi-Botoye ${ }^{1}$, Easter Godwin Nwokah ${ }^{1}$ and Monsi Tombari Pius ${ }^{1}$ \\ ${ }^{1}$ Department of Medical Laboratory Science, Rivers State University, Nkpolu- Oroworukwo-Port Harcourt, Nigeria \\ *Corresponding Author \\ Dr. Amala, Smart Enoch \\ Department of Medical Laboratory Science \\ RSU Port Harcourt \\ Nigeria \\ E-mail:smrtamala@gmail.com \\ Tel. +2348055362681
}

Received:08 August 2021; | Revised:22 September 2021; | Accepted:06 December 2021

\section{Abstract}

Introduction: Pregnancy predisposes women to asymptomatic bacteriuria (AB) and screening of pregnant women for $\mathrm{AB}$ at the early stage of pregnancy is necessary.

Materials and methods: Clean catch midstream urine from pregnant and non-pregnant women were investigated for $\mathrm{AB}$ and UTI by cultural methods using appropriate bacteriological media and standard microbiological procedures.

Results: Out of 210 pregnant women examined for bacteriuria the prevalence rate of $\mathrm{AB}$ was 34 (16.9\%), the prevalence among 200 non-pregnant women used as a control was 8(4.0\%), while the prevalence among 200 symptomatic non-pregnant women was 116(58\%). The prevalence of AB by trimester among pregnant women was 6(2.9) in the first trimester, 20(9.5\%) in the second trimester, and $8(3.8 \%)$ in the third trimester. By age groups, age 26-30 yrs had a high prevalence of 14(6.9\%) among pregnant women, while the prevalence of UTI was high 52(26.0\%) among non-pregnant from age $41 \mathrm{yrs}$ and above. By educational status, graduates among the pregnant women had a prevalence rate of $21(10.0 \%)$, secondary $10(4.8 \%)$, and primary $3(1.4 \%)$. The symptomatic non-pregnant women, graduates had a prevalence rate of $86(43.0 \%)$, secondary $26(13.0 \%)$ and primary $2(2.0 \%)$. AB and symptomatic bacteriuria were high among subjects living in bedroom flats and self-contained than group houses. The percentage occurrences of bacteria from pregnant and non-pregnant women were: The percentage occurrences of bacteria isolated from asymptomatic pregnant women (AP) were E. coli 16(47.1\%), Klebsiella sp. 7(20.6\%), Pseudomonas sp. $1(2.9 \%)$ and S. aureus $10(29.4 \%)$ respectively. The non-pregnant asymptomatic women (AnP) E. coli $8(100 \%)$ and the symptomatic non-pregnant women (SnP) E. coli 52(44.8\%), Klebsiella sp. 36(31.0\%), Proteus sp. 8(6.9\%), Pseudomonas sp. 12(10.3\%) and S. aureus 8(6.9\%) respectively. The overall percentage occurrences of bacteria isolated were E. coli 76(48.1\%), Klebsiella sp. 43(27.2\%), Staphylococci sp. 18(11.4\%), Pseudomonas sp. 12(8.2\%) and Proteus sp. 8(5.1\%). 
Conclusion: $\mathrm{AB}$ in pregnancy and UTI are of public health concern that calls for intervention to prevent deleterious complications on mother and fetus that may require hospitalization. There was a risk factor associated with age and trimester of pregnancy.

Keywords: Bacteriuria,Asymptomatic Pregnancy,Non-Pregnant Symptomatic

\section{Introduction}

Urine from healthy people is sterile and a urinary tract infection (UTI) is an infection involving any part of the urinary system, including the urethra, bladder, ureters, and kidney ${ }^{[1-2]}$. In healthy women, the vagina is colonized by lactobacilli which maintain an acidic environment (low $\mathrm{pH}$ ) that is hostile to other bacteria and also produces hydrogen peroxides which help to eliminate bacteria and reduce the ability of Escherichia coli to adhere to vaginal epithelial cells and cause infection ${ }^{[3]}$. In pregnancy, urinary tract infections (UTI) are underestimated risk factors associated with deadly outcomes and morbidity in developing countries ${ }^{[4]}$. Pregnancy causes hormonal and mechanical changes that result in urinary stasis, vesicoureteral reflux changes coupled with the short urethra (about 3-4 cm) in females, and difficult hygiene as a result of protruding pregnant stomach ${ }^{[5]}$. AB may develop into acute cystitis, pyelonephritis, and other conditions hence screening and treatment of AB/UTI by urine culture is a necessity especially in developing countries just as practiced in the developed countries ${ }^{[6-7-8]}$ The global prevalence of $\mathrm{AB}$ in pregnancy ranges from 3- 35\% ${ }^{[9]}$. Women are at more risk of UTI than men, and pregnancy predisposes women to high risk of infection due to pressure of fetus, dilation of the ureters, and renal pelvis ${ }^{[5-9]}$. UTI is one of the most common medical conditions associated with pregnancy due to physiological changes during pregnancy ${ }^{[4,10,11,12]}$. The use of antimicrobial agents can alter the normal microbiota of the gastrointestinal tract and vagina resulting in drugresistant pathogens. Resistance to antimicrobials is linked with high morbidity, mortality, and increased cost of health care ${ }^{[13,14,15]}$. AB in pregnancy without medical intervention with antibiotics might cause serious complications such as low birth weight, preterm labour, pre-eclampsia, anaemia, hypertension, amonionitis, stillbirth, neonatal death and toxic septicemia ${ }^{[16-17]}$. The most common routes bacteria enters the urinary tract is the opening of a woman's urethra at the vulva. The infection ascends the urethra to the bladder and sometimes to the kidneys or both. The other possible route is through the bloodstream, usually to the kidney ${ }^{[4]}$. A study by ${ }^{[18]}$ reported maximum numbers of positive cases in the second trimester followed by the first trimester and third trimester. Other studies carried out by ${ }^{[5]}$, as well as Turpin and his colleagues, ${ }^{[17]}$ had high asymptomatic bacteriuria in the first and third trimester respectively. Other studies also recorded high prevalence in the second trimester because most pregnant women report late to antenatal clinics for booking. E. coli was pinpointed to be responsible for more than $80 \%$ of all community-acquired UTI. Other bacteria such as Pseudomonas sp., Klebsiella sp. Staphylococci sp., Enterococci sp. and others have also been isolated. Most isolates were resistant to first-line antibiotics. Urine culture remains the gold standard for the screening of asymptomatic bacteriuria during pregnancy and UTI ${ }^{[18]}$.

The work is aimed at determining the prevalence of bacteriuria among pregnant women attending antenatal clinics at the University of Port Harcourt Teaching Hospital (UPTH) and urinary tract infection (UTI) among symptomatic nonpregnant women.

\section{Materials and Methods}

\section{Questionnaire}

Questionnaires were employed in collecting some demographic data from the subjects. It was designed to obtain information from the patients on educational, age, vocational, residential status, and occupation. The questionnaire was designed in a multiple-choice type that required respondents to tick yes or no appropriately. A total of two hundred and ten copies of the questionnaires were administered to pregnant women during antenatal days for months and two hundred (200) copies were administered each to the non-pregnant symptomatic 
and asymptomatic non-pregnant women used as control.

\section{Collection of urine samples:}

Mid-stream, clean-catch urine samples were obtained from the pregnant women attending antenatal clinics in UPTH during their antenatal clinic day. Sterile wide-mouth containers were given to the subjects on arrival at the hospital antenatal clinics, and they were educated on how to collect urine specimens without contamination. The urine specimens were transported to the laboratory immediately for analysis.

Transportation of Sample to the Laboratory

Samples were labeled on collection and immediately transported to the laboratory in a cooler with icebergs for bacteriological analysis and where the delay was envisaged before the cultivation of samples, they were preserved in the refrigerator at $4 \mathrm{oC}$ in the laboratory

\section{Preparation of media}

All media were prepared according to the manufacturer's instructions. Cysteine lactose electrolyte deficient media and Muller Hinton agar were weighed out respectively into a conical flask, dissolved in distilled water, and sterilized by autoclaving at $121^{\circ} \mathrm{C}$ for 15 minutes. About 15 $20 \mathrm{ml}$ of the molten agar was dispensed into disposable Petri-dishes when the temperature had reduced to about $45^{\circ} \mathrm{C}$. They were allowed to set, packed, and stored in a refrigerator for subsequent uses.

\section{Cultivation of samples}

Each urine sample was inoculated and streaked out on Cysteine Lactose Electrolyte Deficient agar plate using a wire loop calibrated to deliver $0.002 \mathrm{~mL}$ of urine. The plates were incubated aerobically at $37^{\circ} \mathrm{C}$ for $18-24$ hours. Colonyforming unit up to 100,000 (105) $\mathrm{CFU} / \mathrm{mL}$ were considered as significant bacteriuria

\section{Identification of Isolates}

Isolates were identified following standard microbiological protocols including Gram stain, carbohydrate metabolisms, indole test, motility test, oxidase test, urease test, catalase test, citrate test,
DNAase test, litmus milk decolorization test, coagulase test.

\section{Antimicrobial susceptibility testing}

Pure culture of each isolate was tested for antimicrobial susceptibility using Kirby-Bauer disc diffusion method on Muller Hinton agar plate as recommended by ${ }^{[19]}$. The antibiotics tested against isolated bacteria were: ciprofloxacin, nalidixic acid, ampicillin, gentamycin, co-trimoxazole, streptomycin, erythromycin, tetracycline and nitrofurantoin against the rods, whereas gentamycin, ciprofloxacin, ofloxacin, ceftatriozone, ampicillin, cloxacillin, clotrimazole and streptomycin were tested against Staphylococci.

\section{Exclusion Criteria}

Women excluded were: (a) Women with a history of antibiotic therapy for the past two weeks, (b) Women with underlying diabetes mellitus (c) Pyrexia

\section{Statistical Analyses}

Where appropriate, statistical analyses were performed using an unpaired t-test in which a twotailed P-value was calculated (GraphPad Prism Software Version 5.03, San Diego, CA). Statistical significance was defined as a P-value of less than 0.05 at a $95 \%$ confidence interval.

\section{Results}

\section{Prevalence of Bacteria}

The prevalence rate of asymptomatic bacteriuria among pregnant women was 34(16.7\%), the prevalence rate of bacteriuria among nonpregnant women used as a control was $8(4.0 \%)$, and the prevalence rate of bacteriuria among symptomatic non-pregnant women was $116(58 \%)$ respectively, as shown in figure 1 .

\section{Prevalence of Bacteriuria in Pregnancy by Trimester}

The prevalence of asymptomatic bacteriuria among pregnant women by trimesters was first trimester 6(2.9\%), second trimester 20(9.7\%), and third trimester $8(3.8 \%)$, respectively. As shown in figure 2. 


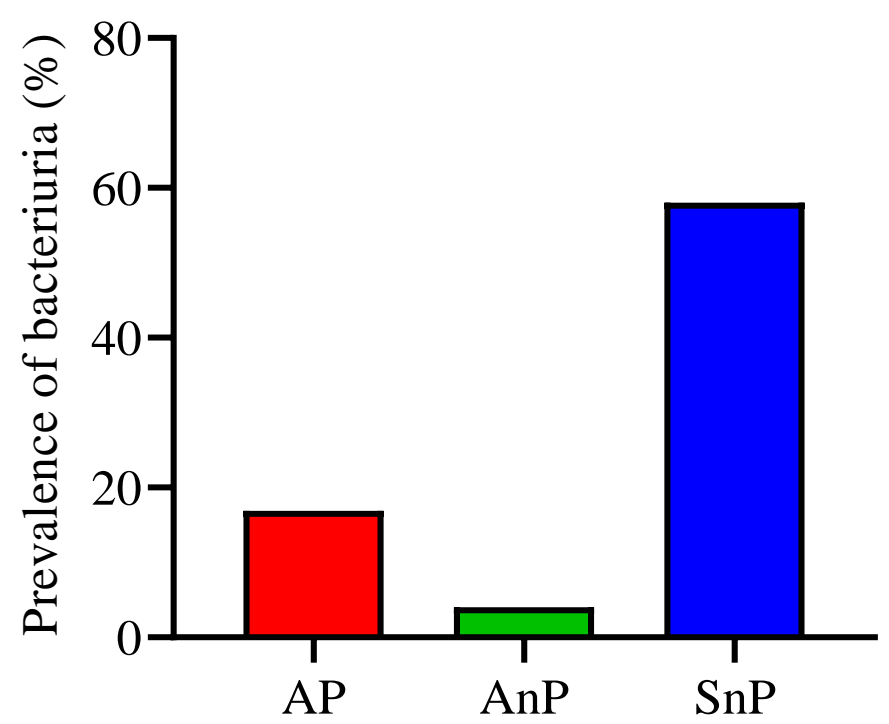

Figure 1: Prevalence of bacteriuria among pregnant and non-pregnant women

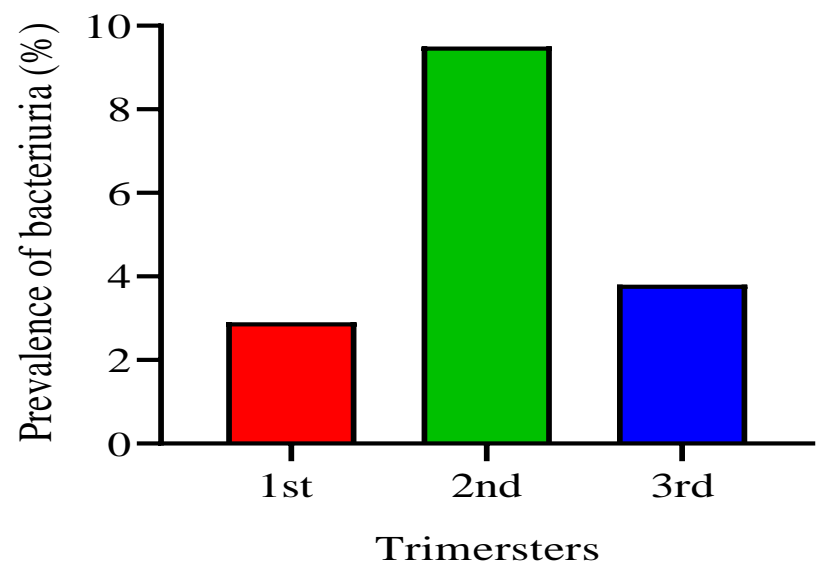

Figure 2: Trimester prevalence of bacteriuria among pregnant women

Prevalence of Bacteriuria by Age Groups

The prevalence of asymptomatic bacteriuria by age groups, the age group $16-20 \mathrm{yrs} \mathrm{SnP}$ were 24, $16(8.0 \%)$ had infection. Age group 20-25 yrs AP were $36,2(1.0 \%)$ had bacteriuria, AnP were 60, $2(1.0 \%)$ and $\mathrm{SnP}$ were $8,4(2.0 \%)$ had infection respctively. Age group 26-30 yrs AP were 102, $14(6.9 \%)$ had bacteriuria, AnP were 66, 4(2.0\%) and $\mathrm{SnP}$ were $36,16(8.0 \%)$ had significant bacteriuria respectively. Age group 31-35yrs AP were $44,9(4.3 \%)$ had bacteriuria, while AnP were $30,2(1.0 \%)$ and SnP were 20, 16(8.0\%) had bacteriuria respectively. Age group 36-40 yrs AP were $24,8(3.8 \%)$ had infection, whereas AnP were 24, none was infected and SnP were 20, 12(6.0\%) were bacteriuric respectively. Age group 40yrs and above SP were $6,1(0.5 \%)$ had bacteriuria and SnP were $96,52(26.0 \%)$ had infection as shown in table 1. 
Table 1: Prevalence of bacteriuria by age group among pregnant and non-pregnant women

\begin{tabular}{|l|c|c|c|c|c|c|}
\hline & \multicolumn{2}{|c|}{$\begin{array}{l}\text { Asymptomatic Pregnant Women } \\
\text { (AP) }\end{array}$} & \multicolumn{2}{l|}{$\begin{array}{l}\text { Asymptomatic non- Pregnant } \\
\text { Women (AnP) }\end{array}$} & \multicolumn{2}{l|}{$\begin{array}{l}\text { Symptomatic non-Pregnant } \\
\text { Women (SnP) }\end{array}$} \\
\hline Age groups & $\begin{array}{l}\text { Number } \\
\text { Sample }\end{array}$ & $\begin{array}{l}\text { Number } \\
\text { Positive }\end{array}$ & $\begin{array}{c}\text { Number } \\
\text { Sampled }\end{array}$ & $\begin{array}{l}\text { Number } \\
\text { Positive }\end{array}$ & $\begin{array}{c}\text { Number } \\
\text { Sampled }\end{array}$ & $\begin{array}{c}\text { Number } \\
\text { Positive }\end{array}$ \\
\hline $16-20$ & 4 & $0(0.00)$ & $0(0.00)$ & $0(0.00)$ & 24 & $16(8.0)$ \\
\hline $21-25$ & 36 & $2(1.0)$ & 60 & $2(1.00)$ & 8 & $4(2.0)$ \\
\hline $26-30$ & 102 & $14(6.9)$ & 66 & $4(2.00)$ & 36 & $16(8.0)$ \\
\hline $31-35$ & 44 & $9(4.3)$ & 30 & $2(1.00)$ & 20 & $16(8.0)$ \\
\hline $36-40$ & 24 & $8(3.8)$ & 24 & $0(0.00)$ & 20 & $12(6.0)$ \\
\hline 41 above & 6 & $1(0.5)$ & 0 & $0(0.00)$ & 92 & $52(26.0)$ \\
\hline TOTAL & 210 & $34(16.2)$ & 200 & $8(4.0)$ & 200 & $116(58.0)$ \\
\hline
\end{tabular}

Numbers in parenthesis $=$ Percentages, Chi-square, df 25.63, 10, $p=0.0043$

\section{Prevalence of Bacteriuria by Educational Status}

The prevalence of asymptomatic bacteriuria by education, graduate asymptomatic pregnant women AP were 146, 21(10.0\%) had bacteriuria, while asymptomatic non-pregnant women (AnP) were $104,8(4.0 \%)$ had bacteriuria, and symptomatic nonpregnant women $(\mathrm{SnP})$ were $136,86(43.0 \%)$ had UTI. The women who had secondary education
(WASC) AP were 60, 10(4.8\%) were bacteriuric, whereas AnP were 70, none was had bacteriuria and SnP 54, 26(13.0\%) had UTI. Women with just primary school education (FSLC) AP were 4, $3(1.4 \%)$ had bacteriuria, AnP were 26, 0(0.00\%) and $\mathrm{SnP}$ were $10,2(2.0 \%)$ had UTI. The prevalence of bacteriuria was high among women with tertiary education in $\mathrm{AP}$, $\mathrm{AnP}$ and $\mathrm{SnP}$ respectively as shown in table 2.

Table 2:Prevalence of Bacteriuria by educational status

\begin{tabular}{|c|c|c|c|c|c|c|}
\hline & \multicolumn{2}{|c|}{$\begin{array}{c}\text { Asymptomatic Pregnant } \\
\text { Women(AP) }\end{array}$} & \multicolumn{2}{c|}{$\begin{array}{c}\text { Asymptomatic non- Pregnant } \\
\text { Women (AnP) }\end{array}$} & \multicolumn{2}{c|}{$\begin{array}{c}\text { Symptomatic non-Pregnant } \\
\text { Women (SnP) }\end{array}$} \\
\hline $\begin{array}{c}\text { Educational } \\
\text { Status }\end{array}$ & $\begin{array}{c}\text { Number } \\
\text { Sample }\end{array}$ & $\begin{array}{c}\text { Number } \\
\text { Positive }\end{array}$ & $\begin{array}{c}\text { Number } \\
\text { Sampled }\end{array}$ & $\begin{array}{c}\text { Number } \\
\text { Positive }\end{array}$ & $\begin{array}{c}\text { Number } \\
\text { Sampled }\end{array}$ & $\begin{array}{c}\text { Number } \\
\text { Positive }\end{array}$ \\
\hline Graduate & 146 & $21(10.0)$ & 104 & $8(4.0)$ & 136 & $86(43.0)$ \\
\hline WASC & 60 & $10(4.8)$ & 70 & $0(0.00)$ & 54 & $26(13.0)$ \\
\hline FSLC & 04 & $3(1.4)$ & 26 & $0(0.00)$ & 10 & $2(2.0)$ \\
\hline TOTAL & 210 & $34(16.2)$ & 200 & $8(4.0)$ & 200 & $116(58.0)$ \\
\hline
\end{tabular}

Numbers in parenthesis $=$ Percentages, Chi-square, $\mathrm{df}, 1.985,4, \mathrm{p}=0.7386$

\section{Prevalence of Bacteriuria by Residential status (Accommodation)}

The prevalence of bacteriuria by residential status among AP in 1 or 2 rooms (public toilet, bathroom and kitchen) were 24, 2(2.9\%) had bacteriuria, AnP were 26, 0(0.00) and ( $\mathrm{SnP})$ were $30,18(9.0 \%)$ had UTI. The women residing in self contained, AP were $42,8(3.8 \%)$ had bacteriuria, while AnP were $70,4(2.0 \%)$ had bacteriuria and SnP were $70,42(21.0 \%)$ had UTI. The subjects living in bedroom flats AP were 114, 20(9.5\%) had bacteriuria, the AnP were 104, 4(2.0\%) had bacteriuria and the $\mathrm{SnP}$ were $100,52(28.0 \%)$ had UTI as shown in table 3. 
Table 3 : Prevalence of bacteriuria by residential status

\begin{tabular}{|l|c|c|c|c|c|c|}
\hline & \multicolumn{2}{|l|}{$\begin{array}{l}\text { Asymptomatic Pregnant } \\
\text { Women (AP) }\end{array}$} & \multicolumn{2}{l|}{$\begin{array}{l}\text { Asymptomatic non- Pregnant } \\
\text { Women (AnP) }\end{array}$} & \multicolumn{2}{l|}{$\begin{array}{l}\text { Asymptomatic non-Pregnant } \\
\text { Women (SnP) }\end{array}$} \\
\hline $\begin{array}{l}\text { Type of } \\
\text { Accommodation }\end{array}$ & $\begin{array}{c}\text { Number } \\
\text { Examined }\end{array}$ & $\begin{array}{l}\text { Number } \\
\text { Positive }\end{array}$ & No. Sampled & No Positive & No Sampled & No Positive \\
\hline 1 or 2 rooms & 24 & $2(2.86)$ & 26 & $8(0.0)$ & 30 & $18(9.0)$ \\
\hline Self-contained & 42 & $8(3.81)$ & 70 & $4(2.0)$ & 70 & $42(21.0)$ \\
\hline Bedroom Flat & 114 & $20(9.52)$ & 104 & $4(2.0)$ & 100 & $56(28.0)$ \\
\hline TOTAL & 210 & $34(16.2)$ & 200 & $8(3.8)$ & 200 & $116(58.0)$ \\
\hline
\end{tabular}

Numbers in parenthesis $=$ percentages. Chi-square, df 2.215, 4. P-value $=0.6962$

Prevalence of Bacteriuria by Residential status (Accommodation)

The prevalence of bacteriuria by residential status among asymptomatic pregnant women (AP) in 1 or 2 rooms (public toilet, bathroom and kitchen) were 24, 2(2.9\%) had bacteriuria, asymptomatic non-pregnant women (AnP) were 26, $0(0.00)$ and symptomatic non-pregnant women
(SnP) were $30,18(9.0 \%)$ had UTI. The women residing in self-contained, AP were $42,8(3.8 \%)$ had bacteriuria, while AnP were $70,4(2.0 \%)$ had bacteriuria and SnP were 70, 42(21.0\%) had UTI. The subjects living in bedroom flats AP were 114, 20(9.5\%) had bacteriuria, the AnP were 104, $4(2.0 \%)$ had bacteriuria and the SnP were 100, $52(28.0 \%)$ had UTI as shown in table 4.

Table 4 Percentage occurrences of isolated bacteria

\begin{tabular}{|l|c|c|c|c|}
\hline Bacteria & $\begin{array}{c}\text { Asymptomatic } \\
\text { Pregnant(AP) }\end{array}$ & $\begin{array}{c}\text { Asymptomatic non- } \\
\text { Pregnant(AnP) }\end{array}$ & $\begin{array}{c}\text { Symptomatic non- } \\
\text { Pregnant (SnP) }\end{array}$ & TOTAL \\
\hline E. coli & $16(47.1)$ & $8(100)$ & $52(44.8)$ & $76(48.1)$ \\
\hline Klebsiella sp. & $7(20.6)$ & $0(0.00)$ & $36(31.0)$ & $43(27.2)$ \\
\hline Proteus sp. & $0(0.00)$ & $0(0.00)$ & $8(6.9)$ & $8(5.1)$ \\
\hline Pseudomonas sp. & $1(2.9)$ & $0(0.00)$ & $12(10.3)$ & $13(8.2)$ \\
\hline S. aureus & $10(29.4)$ & $0(0.00)$ & $8(6.9)$ & $18(11.4)$ \\
\hline TOTAL & $\mathbf{3 4 ( 1 6 . 2 )}$ & $\mathbf{8 ( 4 . 0 )}$ & $\mathbf{1 1 6 ( 5 8 . 0 )}$ & $\mathbf{1 5 8}$ \\
\hline
\end{tabular}

The numbers in parenthesis $=$ percentages, Chi-square, df 126.1, 8. P-value $<0.0001$.

\section{Antibiogram of Isolated Bacteria}

All the bacterial isolates were $100 \%$ susceptible to nitrofurantoin except Pseudomonas sp. which was $23.1 \%$ resistant. E. coli and Klebsiella sp. were $11.5 \%$ resistant to ofloxacin respectively, Proteus sp. were 50\% resistant to ofloxacin whereas Pseudomonas sp. were $100 \%$ susceptible to ofloxacin. E. coli were $62.3 \%$ resistant to gentamycin, while Klebsiella $s p$. and Proteus sp. are $57.2 \%$ and $25.0 \%$ resistant to gentamycin respectively. Pseudomonas $s p$. was completely susceptible to gentamycin. All isolated bacteria were $100 \%$ resistant to ampicillin, tetracycline, streptomycin, nalidixic acid and cotrimoxazole respectively as shown on table 5 . 
Table 5 : Resistance pattern of Gram negative rods isolated

\begin{tabular}{|c|c|c|c|c|c|c|c|c|c|c|c|c|c|}
\hline & \multicolumn{3}{|c|}{ E. coli } & \multicolumn{3}{|c|}{ Klebsiella sp. } & \multicolumn{3}{|c|}{ Proteus sp. } & \multicolumn{3}{|c|}{ Pseudomonas sp. } & \multirow[b]{2}{*}{$\begin{array}{l}\text { Percentage } \\
\text { Resistance }\end{array}$} \\
\hline Antibiotics & PW & AnP & SnP & PW & AnP & SnP & PW & AnP & SnP & PW & AnP & SnP & \\
\hline Nitrofurantoin & $0(0)$ & $0(0)$ & $0(0)$ & $0(0)$ & $0(0)$ & $0(0)$ & Nill & Nill & $0(0)$ & $\begin{array}{c}1 \\
(100)\end{array}$ & Nill & $\begin{array}{c}2 \\
(33.3)\end{array}$ & $3(3.2)$ \\
\hline Ofloxacin & $0(0)$ & $0(0)$ & $\begin{array}{c}3 . \\
(11.5)\end{array}$ & $0(0)$ & $0(0)$ & $\begin{array}{c}3 \\
(11.5)\end{array}$ & Nill & Nill & $\begin{array}{c}2 \\
(50)\end{array}$ & $0(0)$ & Nill & $0(0)$ & $8(8.5)$ \\
\hline Gentamycin & $\begin{array}{c}5 \\
(31.3)\end{array}$ & $\begin{array}{c}1 \\
(25)\end{array}$ & $\begin{array}{c}4 \\
(15.3)\end{array}$ & $0(0)$ & $0(0)$ & $\begin{array}{c}4 \\
(15.3)\end{array}$ & Nill & Nill & $\begin{array}{c}2 \\
(50)\end{array}$ & $0(0)$ & Nill & $0(0)$ & $18(19.2)$ \\
\hline Nalidixic acid & $\begin{array}{c}16 . \\
(100)\end{array}$ & $\begin{array}{c}4 \\
(100)\end{array}$ & $\begin{array}{c}26 \\
(100)\end{array}$ & $\begin{array}{c}7 \\
(100)\end{array}$ & $\begin{array}{c}4 \\
(100)\end{array}$ & $\begin{array}{c}26 \\
(100)\end{array}$ & Nill & Nill & $\begin{array}{c}4 \\
(100)\end{array}$ & $\begin{array}{c}1 \\
(100)\end{array}$ & Nill & $\begin{array}{c}6 \\
(100)\end{array}$ & $94(100)$ \\
\hline Co-trimozole & $\begin{array}{c}16 \\
(100)\end{array}$ & $\begin{array}{c}4 \\
(100)\end{array}$ & $\begin{array}{c}25 \\
(96.2)\end{array}$ & $\begin{array}{c}7 \\
(100)\end{array}$ & $\begin{array}{c}4 \\
(100)\end{array}$ & $\begin{array}{c}26 \\
(100)\end{array}$ & Nill & Nill & $\begin{array}{c}4 \\
(100)\end{array}$ & $\begin{array}{c}1 \\
(100)\end{array}$ & Nill & $\begin{array}{c}6 \\
(100)\end{array}$ & 93(98.9) \\
\hline Ampicillin & $\begin{array}{c}16 \\
(100)\end{array}$ & $\begin{array}{c}4 \\
(100)\end{array}$ & $\begin{array}{c}26 \\
(100)\end{array}$ & $\begin{array}{c}7 \\
(100)\end{array}$ & $\begin{array}{c}4 \\
(100)\end{array}$ & $\begin{array}{c}26 \\
(100)\end{array}$ & Nill & Nill & $\begin{array}{c}4 \\
(100)\end{array}$ & $\begin{array}{c}1 \\
(100)\end{array}$ & Nill & $\begin{array}{c}6 \\
(100)\end{array}$ & $94(100)$ \\
\hline Tetracyclin & $\begin{array}{c}16 \\
(100)\end{array}$ & $\begin{array}{c}4 \\
(100)\end{array}$ & $\begin{array}{c}26 \\
(100)\end{array}$ & $\begin{array}{c}7 \\
(100)\end{array}$ & $\begin{array}{c}4 \\
(100)\end{array}$ & $\begin{array}{c}26 \\
(100)\end{array}$ & Nill & Nill & $\begin{array}{c}4 \\
(100)\end{array}$ & $\begin{array}{c}1 \\
(100)\end{array}$ & Nill & $\begin{array}{c}6 \\
(100)\end{array}$ & $94(100)$ \\
\hline Streptomycin & $\begin{array}{c}16 \\
(100)\end{array}$ & $\begin{array}{c}4 \\
(100)\end{array}$ & $\begin{array}{c}26 \\
(100)\end{array}$ & $\begin{array}{c}7 \\
(100)\end{array}$ & $\begin{array}{c}4 \\
(100)\end{array}$ & $\begin{array}{c}26 \\
(100)\end{array}$ & Nill & Nill & $\begin{array}{c}4 \\
(100)\end{array}$ & $\begin{array}{c}1 \\
(100)\end{array}$ & Nill & $\begin{array}{c}6 \\
(100)\end{array}$ & $94(100)$ \\
\hline
\end{tabular}

Numbers in parenthesis $=$ Percentage resistance, Nil = No growth, $\mathrm{PW}=$ Pregnant women, NPA= Non Pregnant women (control), NPS=Non pregnant symptomatic women.

Resistance Pattern of Staphylococcus aureus to Antimicrobial Agents Tested Against it

S.aureus were $11.1 \%$ resistant to gentamycin, $5.5 \%$ to ciprofloxacin, $16.7 \%$ to ofloxacin, $22.2 \%$ to ceftatriozone and $77.8 \%$ each to ampicillin, cloxacillin and cotrimozole respectively as shown on table 6.

Table 6 Resistance pattern of Staphylococcus aureus isolates

\begin{tabular}{|l|c|c|c|c|}
\hline & \multicolumn{3}{|c|}{ Staphylococcus aureus } & \multicolumn{1}{c|}{$\begin{array}{c}\text { Percentage } \\
\text { Resistance }\end{array}$} \\
\hline Antibiotics & AP & AnP & SnP & $2(4.3)$ \\
\hline Gentamycin & $2(20)$ & Nill & $1(0)$ & $3(21.4)$ \\
\hline Ciprofloxacin & $0(0)$ & Nill & $3(25)$ & $4(28.6)$ \\
\hline Ofloxacin & $0(0)$ & Nill & $4(100)$ & $4(28.6)$ \\
\hline Ceftatriozone & $0(0)$ & Nill & $4(100)$ & $14(100)$ \\
\hline Ampicillin & $10(100)$ & Nill & $4(100)$ & $14(100)$ \\
\hline Cloxacillin & $10(100)$ & Nill & $4(100)$ & $14(100)$ \\
\hline Cotrimozole & $10(100)$ & Nill & $4(100)$ & I4(100) \\
\hline Streptomycin & $10(100)$ & &
\end{tabular}

Numbers in parenthesis=percentage resistance, Nil=no growth

\section{Discussions}

The prevalence rate of bacteriuria among pregnant women (AP) attending antenatal at the
University of Port Harcourt Teaching Hospital (UPTH), was 34 (16.9\%) and the prevalence rate for the asymptomatic non-pregnant women was $8(4.0 \%)$. The prevalence among symptomatic non- 
pregnant women was $116(58 \%)$. The prevalence rates of bacteriuria obtained in some regions or zones in Nigeria are not in agreement with the result obtained from this research. South-Eastern Nigeria ${ }^{[20]}$ had a prevalence rate of $52.0 \%$ in Benin City ${ }^{[21]}$ had a prevalence rate of $50 \%$ also in Benin City and Akure ${ }^{[22]}$ recorded a prevalence rate of $61 \%$. In some African countries, the results got were also at variance with the findings of this study, such as ${ }^{[23]}$ in Egypt had a prevalence rate of $53.5 \%$, ${ }^{[24]}$ in Ethiopia had a prevalence rate of $21.2 \%$ and Uganda ${ }^{[25]}$ had a prevalence rate of $32.2 \%$. Beyond Africa, Kirkuk City Irag ${ }^{[26]}$ obtained a bacteriuria prevalence rate of $43 \%$.

Other researchers in Nigeria had lower prevalence rates than those already cited above such as ${ }^{[27]}$ in Port Harcourt recorded a prevalence rate of $29.5 \%$, while ${ }^{[28]}$ had a prevalence rate of $29.5 \%$. A related study at Abakilike Nigeria ${ }^{[29]}$ reported a prevalence rate of bacteriuria to be $24.7 \%$. These values were slightly higher compared to the value obtained in this study. Tantamount with the result of this research were the findings of ${ }^{[30]}$ who had a prevalence rate of $18.21 \%$ in Enugu, and in Ghana ${ }^{[31]}$ obtained a bacteriuria prevalence rate of $17.5 \%$, these were synonymous with the value recorded in this study. Some researchers had even recorded lower prevalence rates of bacteriuria such as ${ }^{[32]}$ $10.7 \%$ in Ibadan. Pakistan ${ }^{[33]}$ recorded a prevalence rate of $5 \%$, while ${ }^{[34]}$ in Cameron reported a prevalence rate of $7.8 \%$, and ${ }^{[35]}$ in Tanzania had a prevalence of $8.9 \%$. These results clearly showed that different zones, regions, or countries may have varying prevalence rates of bacteriuria. It could depend on the unawareness of predisposing factors associated with bacteriuria such as individual or personal hygiene, juxtapose of the female anus with the vagina, short female urethra, pressure due to sexual massage, pregnancy conditions and other predisposing factors due to common practices in the area. The prevalence of UTI among SnP was 58\% from this study which was in line with $50.3 \%$ obtained by ${ }^{[36]}$ in Iraq among the non-pregnant women, UTI was more prevalent among subjects from age 40 yrs and above as was also noted by ${ }^{[36]}$

The prevalence of $\mathrm{AB}$ among AP by trimester was high in the second trimester 20(9.5\%). Some studies have shown a high prevalence rate of bacteriuria in the third trimester which was not in conformity with this research such as ${ }^{[28]}$ had a prevalence rate of $65 \%$ in the $3^{\text {rd }}$ trimester, [37] reported a high prevalence in the third trimester. In agreement with the result obtained in this research ${ }^{[30]}$ in Enugu stated a high prevalence in the second trimester in Abakaliki, ${ }^{[28]}$ had a high prevalence rate of $21,9 \%$ also in the second trimester. Another African country such as Ethiopia ${ }^{[38]}$ had a high prevalence rate of bacteriuria in the second trimester. Some pregnant women are jaded from registering at antenatal clinics in the first trimester when $\mathrm{AB}$ could have been detected early and arrested clinically by interventions with antimicrobial agents. Statistical analysis showed that there was a significant difference at $\mathrm{P}<0.05$ by trimester.

The prevalence of $\mathrm{AB}$ by education status of the subjects showed that subjects with tertiary educational qualifications were more predisposed to $\mathrm{AB}$ among the AP 21(10.0\%) and UTI among SnP $86(43 \%)$. This result is contrary to the verdict of ${ }^{[39]}$ had a high bacteriuria prevalence rate of $36(55.4 \%)$ among subjects with secondary education in Port Harcourt, Nigeria; ${ }^{[40]}$ recorded $52 \%$ among subjects who had secondary education. ${ }^{[32]}$ had a high prevalence of bacteriuria 6(14.6\%) among women with secondary education in Ibadan. In Pakistan ${ }^{[41]}$ also obtained a high prevalence rate of $45 \%$ among subjects with secondary education, which were not in conformity with the result of this research. Benin City ${ }^{[28]}$ had a high prevalence rate of $65.6 \%$ among illiterates and ${ }^{[26]}$ in Iraq communicated a prevalence rate of $48.4 \%$ among illiterate women which differs from the report of this study. In parallel with our result, [35] conveyed a high prevalence of $52 \%$ among women with tertiary levels of education. In Northern India ${ }^{[9]}$ had a high prevalence among the educated, ${ }^{[31]}$ in Ghana also had a high prevalence of $26.7 \%$ among women with tertiary level of education which was analogous with the account of this research. Most educated women are either working class or in different types of business which may expose them to ex-marital sex that may predispose them to genitourinary tract infection. Voiding in public toilets which is not hygienically maintained as those in the developed countries may expose women to $\mathrm{AB}$ and or UTI. Statistical analysis at $\mathrm{P}<0.05$ did not show a 
significant difference in the educational status of the women.

The prevalence of bacteriuria by age groups from this study was high $14(6.9 \%)$ among AP in the age group 26-30 yrs. In Akure Nigeria, ${ }^{[22]}$ had a high prevalence among pregnant women in the age group 25-34 yrs 101(52.2\%), Ibadan Nigeria ${ }^{[28]}$ had a high prevalence rate of bacteriuria $71.4 \%$ among the age group 21-35 yrs. In Port Harcourt, Nigeria [27] recorded a prevalence rate of $40 \%$ in UPTH among subjects in age the group $30-34$ yrs. ${ }^{[32]}$ had a high prevalence of $11.5 \%$ in Ibadan Nigeria among subjects in age the group 26-35 yrs. Jos, Northern Nigeria, the prevalence of bacteriuria was high among the age group 24-28 yrs was $5.1 \%{ }^{[39]}$. In other countries ${ }^{[40]}$ in Pakistan had a similarly high prevalence of $55 \%$ among this same age group. Tanzania ${ }^{[35]}$ had a high prevalence of $78 \%$ among the age group 21-30 yrs. In Ghana ${ }^{[31]}$ also had a high prevalence of $18.8 \%$ among age $26-30 \mathrm{yrs}$ and in Iraq ${ }^{[26]}$ had a high prevalence of $58.4 \%$ among the age group 21- 30 yrs. These age groups are noted to be very active in social and sexual activities which may account for the high prevalence among them ${ }^{[5]}$. There was statistical significance difference among the AP by age at $\mathrm{P}<0.05$.

Grouping the women by residential status was concomitant with socioeconomic status. AB increased with better accommodation. The prevalence of $\mathrm{AB}$ among those living in bedroom flats was 20(9.5\%) for AP and 56(28.0\%) for SnP. Related research [27] and ${ }^{[40]}$ conveyed a high prevalence of $\mathrm{AB}$ among the middle class which differs from the result of this research. [9] also reported a high prevalence of $\mathrm{AB}$ among the highclass women which consents with our result.

The percentage occurrences of bacteria isolated from $\mathrm{AP}, \mathrm{AnP}$ and $\mathrm{SnP}$ from this study were E. coli 76(48.1\%), Klebsiella sp. 43(27.2\%), Staphylococci sp. 18(11.4\%), Pseudomonas sp. 13(8.2\%) and Proteus sp. 8(5.1\%). Our result differed from what was arrived at by researchers such as [29] in Abakiliki Nigeria recorded Staphylococcus as the most prevalent bacteria with a percentage occurrence of $24.7 \%,{ }^{[26]}$ record had a percentage occurrence of $20.6 \%$ Staphylococci. ${ }^{[32]}$ had Klebsiella sp. 8(36.8\%) as the highest bacteria in percentage occurrence. In alignment with our work ${ }^{[27]}$ in Port Harcourt noted that E. coli was highest in percentage occurrence $24.6 \%$, in Akure E. coli accounted for 58(31.7\%), in Jos E. coli was predominantly $71.4 \%$, in another study of $\mathrm{AB}$ in Enugu ${ }^{[30]}$ recorded E. coli as $26.6 \%$ and Benin City ${ }^{[28]}$ E. coli $54.0 \%$ in $\mathrm{AB}$ among pregnant women. Other countries such as Ghana ${ }^{[31]}$ recorded E. coli as the most prevalent bacteria $62.5 \%$, Uganda E. coli was highest $41.2 \%$, in Ethiopia ${ }^{[24]}$ had E. coli to be $34.6 \%$. In other countries, E. coli was also documented as the most prevalent bacteria in Tanzania $50 \%{ }^{[35]}$. Iran E. coli accounted for $58 \%$ ${ }^{[33]}$. All the recent references were in line with our findings.

E. coli, Klebsiella sp., and Proteus sp. were bacteria that may be associated with the human and animal intestine and infections with these bacteria could be linked to faecal contamination. In the female, the anus and the vagina juxtapose in addition to the short urethra that enables bacteria to transverse to the bladder easily ${ }^{[5]}$. Staphylococci are normal human microbiota inhabiting nostrils, skins, palms etc. infections by Staphylococci may come from normal flora and or by contacts with infected materials. Pseudomonas is a recalcitrant organism that can establish in sinks, disinfectants and form biofilms on moist surfaces. It may cause infection from unimagined contaminated sources, even faeces.

The result of antimicrobial susceptibility testing of all isolated suggests nitrofurantoin which showed the highest susceptibility to isolated bacteria as the first drug of choice, followed by ofloxacin and gentamycin in the treatments of $\mathrm{AB}$ and UTI associated with Gram-negative rods. Staphylococci sp. gentamycin, ciprofloxacin, ofloxacin and ceftriaxone respectively may be considered in that order for treatment of infections caused by Staphylococci sp. The result of the antimicrobial susceptibility portrays the challenge posed on the health sector in the treatment of $\mathrm{AB} / \mathrm{UTIs}$ as a result of developments of antimicrobial resistance to antimicrobial drugs.

\section{Conclusion}

Our research reported risk factors such as conception age in the second trimester, maternal age group 26-30yrs and age $40 \mathrm{yrs}$ and above for $\mathrm{SnP}$ 
women. There was no significant association between the level of education and socioeconomic status with AB/UTI. E. coli was the most prevalent bacteria isolated from the urine of $\mathrm{PW}, \mathrm{PnP}$ and $\mathrm{SnP}$ respectively.

\section{References}

1 Centers for Disease Control and Prevention, National Center for Emerging and Zoonotic Infectious Diseases (NCEZID), Division of Healthcare Quality Promotion (DHQP 2015) A urinary tract infection (UTI) is an infection involving any part of the urinary system, including urethra, bladder, ureters, and kidney.

2 Steward D.K; Blood, G.L.; Cohen, R.L.; Smith, T.W. Failure of the urinalysis and quantitative urine culture in Diagnosing symptomatic urinary tract infections in patients with long term urinary catheter. American Journal of infections control, 1985, 154-160, DOI: 10.1016/0196-6553(85)90102-6

3 Cheesbrough, M.Microbiological Tests.District Laboratory Practice in Tropical Countries, Part 2, 2nd ed. 2006; Cambridge, Cambridge University Press, pp105 114-159.

4 Gilbert NM, O'Brien VP, Hultgren S, Macones G, Lewis WG, Lewis AL. Urinary tract infection as a preventable cause of pregnancy complications: opportunities, challenges, and a global call to action. Glob Adv Health Med 2013; 2(5): 59-69 DOI: 10.7453/gahmj.2013.061

5 Amala, S.E.; Nwokah, E.G. Prevalence of asymptomatic bacteriuria among pregnant women attending antennal in Port-Harcourt Township Nigeria and antibiogram of isolated bacteria. American Journal of Biomedical Science, 2015, 7(2), 125-133. DOI: $\underline{10.5099 / a j 150200125}$

6 Nicolle LE, Bradley S, Colgan R, Rice JC, Schaeffer A, Hooton TM, Infectious Diseases Society of A, American Society of N, American Geriatric S. Infectious Diseases Society of America guidelines for the diagnosis and treatment of asymptomatic bacteriuria in adults. Clin Infect Dis 2005; 40(5): 643-654 DOI: 10.1086/427507
7 Nicolle LE. Asymptomatic Bacteriuria and Bacterial Interference. Microbiol Spectr 2015; 3(5) DOI: $10.1128 / \mathrm{microbiolspec}$.UTI-00012012

8 World Health Organization. WHO recommendations on antental care for a positive pregnancy experience, Geneva, 2016

9 Kant, S.; Lohiya, A.; Kapil, A.; Gupta, S.K. Urinary tract infection among pregnant women at a secondary level hospital in Northern India, Indian J Public Health, 2017, 61, 118-123. https://www.ijph.in/text.asp?2017/61/2/118/20 7410

10 Abdullah, A.A; Al-Moslih, M.I. Prevalence of asymptomatic bacteriuria Necessity for exploring newer treatment options, $\boldsymbol{J} \boldsymbol{L a b}$ Physician, 2011, 3, 98-103

11 Tempera, G.; Furneri, P.M.; Cianci, A.; Incognito, T.; Marano, M.R.; Drago, F. The impact of pruli floxacin on vaginal lactobacillus microflora an invivo study, $J$. Chemother, 2009, 21(6), 646-650. DOI: 10.1179/joc.2009.21.6.646

12 Hillier S, Roberts Z, Dunstan F, Butler C, Howard A, Palmer S. Prior antibiotics and risk of antibiotic-resistant community-acquired urinary tract infection: a case-control study. $J$ Antimicrob Chemother 2007; 60(1): 92-99 [PMID: 17540675 DOI: 10.1093/jac/dkm141]

13 Pujades-Rodrigueza, M.; Robert, M.W.; Wilcox, J.S. Lower Urinary Tract Infection: Management, Outcomes and Risk Factors for Antibiotic Re-prescription in Primary Care, $\boldsymbol{E}$ Clinical Medicine, 2019, 14, 23-31.

14 Glaser AP, Schaeffer AJ. Urinary Tract Infection and Bacteriuria in Pregnancy. Urol Clin North Am 2015; 42(4): 547-560 [PMID: 26475951 DOI:10.1016/j.ucl.2015.05.004]

15 Izadi, B.; Rostami-Far, Z.;Jalilian, N.;Sedigheh, K.; Amir, A.; Seyed, H.M.; Rostami-Far, M. Urinary tract infection (UTI) as a risk factor of severe preeclampsia, Global Journal of Health Science, 2016, 8(11), 77. DOI: 10.5539/gjhs.v8n11p77

16 Turpin C, Minkah B, Danso K, Frimpong E. Asymptomatic bacteriuria in pregnant women attending antenatal clinic at komfo anokye teaching hospital, kumasi, ghana. Ghana Med 
J 2007; 41(1): 26-29 [PMID: 17622336 PMCID: PMC1890540]

17 Rajshekhar. D.; Keruru, U.S. Prevalence of Asymptomatic Bacteriuria among Pregnant women in a tertiary care hospital, International Journal of Scientific and Research Publications, 2013, 3, 2250-3153

18 Gayathree, I.;Shetty, S.; Deshpande, S.R.; Venkatesh, D.T. Screening for asymptomatic bacteriuria in pregnancy. An evaluation of various screening tests in Hassan District Hospital, India, J.C D R , 2010, 4, 2702-2706

19 Clinical and Laboratory Standards Institute. Performance standards for antimicrobial susceptibility testing: Approved StandardEleventh Edition 2012; CLSI Document M02A11

20 Obiogbolu, C.H.;Okonko, I.O.; Anyamere,C.O.; Adedeji, A.O.; Akanbi, A.; Ogun, A.; Ejembi, J.; Faleye, T.O.C. (2009) Incidence of Urinary Tract Infections (UTIs) among Pregnant women in Akwa metropolis, Southeastern Nigeria, Scientific Research and Essay, 2009, 4(8), 820-824

21 Oladeinde BH, Omoregie R, Oladeinde OB. Asymptomatic urinary tract infection among pregnant women receiving ante-natal care in a traditional birth home in Benin City, Nigeria. Ethiop J Health Sci 2015; 25(1): 3-8 DOI: 10.4314/ejhs.v25i1.2

22 Simon-Oke, I.A.;Odeyemi, O.; Oniya, M. Prevalence of urinary tract infections and risk factors among pregnant women attending antenatal clinics in government primary healthcare centers in Akure, Nigeria, $N$ Niger J Clin Res, 2020, 9, 24-30

23 Mirfat, M.L.A. Urinary Tract Infection among Pregnant Women and its associated risk factors a cross-sectional study, Biomedical \& Pharmacology Journal, 2019, 12(4), 20032010. DOI: $10.13005 / \mathrm{bpj} / 1832$

24 Tadesse E, Teshome M, Merid Y, Kibret B, Shimelis T. Asymptomatic urinary tract infection among pregnant women attending the antenatal clinic of Hawassa Referral Hospital, Southern Ethiopia. BMC Res Notes 2014; 7 : 155 DOI: $\underline{10.1186 / 1756-0500-7-155}$

25 Odoki, M.; Adamu, A.A.; Julius, T.; Josephat, N.M.; Eddie, W.; Charles, D.K.; Ezera, A.;
Joel, B. Prevalence of Bacterial Urinary Tract Infections and Associated Factors among Patients Attending Hospitals in Bushenyi District, Uganda, International Journal of Microbiology, 2019, $8 . \quad$ DOI: $\underline{10.1155 / 2019 / 424678}$

26 Almukhtar, S.H. Urinary Tract Infection among Women Aged (18-40) Years Old in Kirkuk City, Iraq, The Open Nursing Journal, 2018, $12, \quad 248-254-259 . \quad$ DOI: $10.2174 / 1874434601812010248$

27 Izuchukwu KE, Oranu EO, Bassey G, Orazulike NC. Maternofetal outcome of asymptomatic bacteriuria among pregnant women in a Nigerian Teaching Hospital. Pan Afr Med J 2017; 27: 69 DOI: 10.11604/pamj.2017.27.69.10492

28 Bankole, H.O.;Richard, O.; Oladapo, O.B. Asymptomatic Urinary Tract Infection Among Pregnant Women Receiving Ante-natal Care In A Traditional Birth Home In Benin City, Nigeria, Ethiop J Health Sci, 2015, 25,(1). DOI: $10.4314 /$ ejhs.v25i1.2

29 Onu FA, Ajah LO, Ezeonu PO, Umeora OU, Ibekwe PC, Ajah MI. Profile and microbiological isolates of asymptomatic bacteriuria among pregnant women in Abakaliki, Nigeria. Infect Drug Resist 2015; 8: 231-235 DOI: $10.2147 /$ IDR.S87052

30 Oli AN, Akabueze VB, Ezeudu CE, Eleje GU, Ejiofor OS, Ezebialu IU, Oguejiofor CB, Ekejindu IM, Emechebe GO, Okeke KN. Bacteriology and Antibiogram of Urinary Tract Infection Among Female Patients in a Tertiary Health Facility in South Eastern Nigeria. Open Microbiol J 2017; 11: 292-300 DOI: $\underline{10.2174 / 1874285801711010292}$

31 Acheampong, D.O.;Afoakwah, M.K.; Boye, A.; Opoku, R.; Kwakye-Nuako, G.; Adokoh, C.K. Evaluation of Diagnostic Methods and Antimicrobial Susceptibility Pattern of Asymptomatic Bacteriuria Among Pregnant Women in Ashanti Region, Ghana, J Explor Res Pharmacol, 2018, 3(3),78. URI: http://hdl.handle.net/123456789/5716

32 Awonuga DO, Fawole AO, Dada-Adegbola HO, Olola FA, Awonuga OM. Predictors of asymptomatic bacteriuria among obstetric 
population in Ibadan. Niger J Med 2010; 19(2): 188-193 DOI: $\underline{10.4314 / \text { njm.v19i2.56517 }}$

33 Enayat,K.;Fariba, F.;Bahram, N. Asymptomatic bacteriuria among pregnant women referred to outpatient clinics in Sanandaj, Iran, Int Braz J Urol, 2008, 34(6), 699-707

34 Mokube MN, Atashili J, Halle-Ekane GE, Ikomey GM, Ndumbe PM. Bacteriuria amongst pregnant women in the Buea Health District, Cameroon: prevalence, predictors, antibiotic susceptibility patterns and diagnosis. PLoS One 2013; 8(8): e71086 DOI: 10.1371/journal.pone.0071086

35 Mwei, K.M. Asymptomatic bacteriuria among pregnant women attending antenatal clinic at Kilimanjaro Christian Medical Centre in Northern Tanzania, Research Article Clinical Practice, 2018, 15(6), 6, e00151

36 Laily, F.; Lutan, D.; Amelia, S.; Tala, M.R.Z.; Nasution, T.A. Associated risk factors for urinary tract infection among pregnant women at Puskesmas Kenangan, Deli Serdang district, Earth and Environmental Science, 2018, 125, 012035 doi : $10.1088 / 1755-1315 / 125 / 1 / 012035$
37 Manjula, N.G.; Girish, C.M.; Shripad, A.P.; Subhashchandra, M.G.; Channappa, T.S. Incidence of Urinary Tract Infections and Its Aetiological Agents among Pregnant Women in Karnataka Region, Advances in Microbiology, 2013, 3(6), 473-478, DOI:10.4236/aim.2013.36063

38 Edae, M.; Teklemariam, Z.; Weldegebreal, F.; Abate, D. Asymptomatic Bacteriuria among Pregnant Women Attending Antenatal Care at Hiwot Fana Specialized University Hospital, Harar, Eastern Ethiopia: Magnitude, Associated Factors, and Antimicrobial Susceptibility Pattern, International Journal of Microbiology, 2020, DOI: $\underline{10.1155 / 2020 / 1763931}$

39 Banda, J.M.;Deborah, C.;Zakka, S.;Surajudeen, A.J.; Baba, J.; Sani, S.D.M.; James, G.D. Prevalence of asymptomatic Bacteriuria among Pregnant Women Attending Antenatal Clinic at Plateau State Specialist Hospital, Jos, Nigeria, Archives of Microbiology \& Immunology, 2020, 4, 121-130

40 Ali, R.; Afzal U.; Kausar, S. Asymptomatic Bacteriuria Among Pregnant Women, A.P.M.C, 2011, 5(2). 